\section{Government policy attacked}

A LEADING Polish geologist has called for a rethinking of the government's attitude to one of Poland's major natural resources sulphur. Interviewed in the party daily, Trybuna Ludu, Dr Stanislaw Pawlowski, a member of the Polish Academy of Sciences, urged the need for legislation to govern the exploitation of mineral resources, and criticized current attitudes on the development of mining areas.

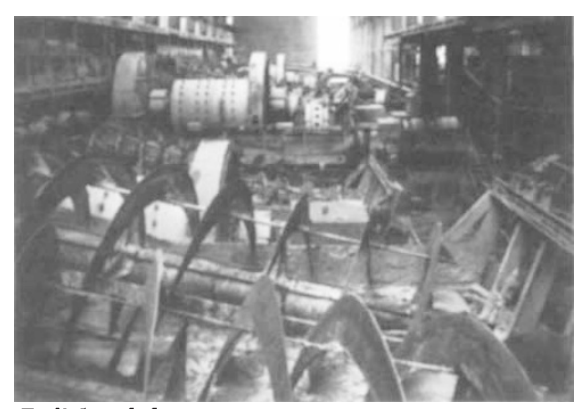

Polish sulphur mine

During the past few decades, he said, "a great number of irreversible errors have been made",

Poland, according to the nineteenth century "father of Polish geology", Stanislaw Staszic, is "built on sulphur", but the vast reserves that form the basis of the modern sulphur industry were not found until the $1950 \mathrm{~s}$, although preliminary surveys started in 1937, and the resulting field data were secretly processed during the Second World War under Nazi occupation.

Ostensibly, the Trybuna Ludu interview deals with Pawlowski's role in the discovery of sulphur along the ZawichostKurdwanów dislocation along the Vistula river in the region of Sandomierz and Tarnobrzeg. Pawlowski, however, is concerned not so much with his discovery in 1953 of vast sulphur beds at depths of as little as $15 \mathrm{~m}$ but rather the bureaucratic difficulties which followed.

Before the new sulphur beds were discovered, a project had been floated for the construction of a sulphuric acid works at Gackie near Buska-Zdroj, using gypsum as the raw material. Although this process at least three times as expensive as the production of sulphuric acid from native sulphur, Pawlowski had a hard fight to get the decision-makers to change their minds, principally because they feared that the new beds would prove insufficient. Since then, the mood has changed and the abundance of sulphur has led to a somewhat careless attitude. The Basznia mine near Lubaczów, with an annual output of a mere 20,000 tonnes, is officially considered to be of little importance (wrongly so, says Pawlowski) although a number of mines in the United States have outputs of this order.

More seriously, inefficient mining is causing the irretrievable loss of usable sulphur. The organization of mining work is far from satisfactory, says Pawlowski, and many tonnes of workable sulphur are being left in the ground to be lost forever because "tectonic, hydrological and other conditions are changing".

Poland uses two methods of sulphur extraction. In the deep deposits at Grzybów and Jeziórko, a modern underground liquefaction process, using super-heated water, is employed, yielding a high-quality product. The shallow beds discovered by Pawlowski, however, are worked by opencast techniques. Apologists for the latter method have always stressed that operations are carried out with due regard for the environment, but in the sulphur town of Tarnobrzeg, for example, the trees have a sickly yellowish tinge and the air has a strong sulphurous smell. Pawlowski attacks the whole concept of the planning of Tarnobrzeg, which, he says, has been allowed to expand towards the mining area and is now surrounded on three sides, by mineworkings.

Pawlowski's radical solution would be to give the town "a window on the west" by building a bridge across the Vistula, and constructing a new town on the west bank where the inhabitants could enjoy "clean air, fresh water and uncontaminated food". At the same time, Pawlowski urges new environmental controls in sulphurmining areas, including the designation of green belts. Geologists working on the sulphur beds of the Osieka-Baranów region have, says Pawlowski, warned of the pollution threat inherent in working the deposits. As far as he knows, however, no action has so far been taken, even though Baranów Castle, an important historical monument, would be directly threatened.

Vera Rich

\title{
Hungarian flint-mine found
}

\section{Budapest}

THE discovery of a palaeolithic flint-mine at Farkasrét (Wolves' Field) on the outskirts of Budapest in Hungary seems likely to generate radical rethinking about the technology of the Mousterian era $(50,000 \mathrm{BP})$. Although flint-mines and ateliers of this period are fairly common in Europe, the Budapest find includes not only flint shards left after the shaping of tools but also mining implements made from deer antlers. Similar picks and hammers have previously been found, but only from the Neolithic era. Indeed, since the form of the antlers imposes severe constraints on the design of such picks and hammers, Dr Veronica Gabori-Csank of the Budapest Historical Museum, who found them, assumed that what she was investigating was a neolithic deposit. Only on 21 June, the thirtieth day of the dig, did she discover among the implements a typical Mousterian hand-axe, apparently discarded by the artificer because of a flaw in the stone. Since then, other Mousterian flint artefacts have come to light, convincing Dr Gabori-Csank that the mining implements date from some $50,000 \mathrm{BP}$, from a temperate period before the Wurmian glaciation.

The Farkasrét site has been known as a potential source of prehistoric material since 1969 , when a deer-antler mining tool was discovered by a university student, but he neglected to mark the exact site, noting only that it came from a cliff alongside a surburban road. This lack of precision, and the somewhat atypical nature of his find meant, however, that the site was neglected until early this year, when another implement was found in the exposed face of the cliff, and excavations were started.
Examination of the exposed cliff face revealed a cross-section of a former gulley, now completely filled by detritus. Working in only a small section of this gulley, $\mathrm{Dr}$ Gabori-Csank has so far discovered fiftyeight magnificent specimens of mining tools, which are now undergoing conservation treatment. The high quality of the specimens, however, has raised problems with carbon-14 dating. Although the Nuclear Research Institute of the Hungarian Academy of Sciences at Debrecen would seem the obvious place for such tests, the outmoded equipment there would require the destruction of some 1.5 $\mathrm{kg}$ of material. This Dr Gabori-Csank would be reluctant to sanction, particularly since the Mousterian finds provide strong prima facie evidence of the palaeolithic origin of the tools. Carbon-14 dating will therefore have to wait until the coming winter, when a slot has been reserved for it at a unit in Hanover, which will require the sacrifice of only a few grams.

Hungary may be short of modern equipment, but it is not short of enthusiasm. The new rector of Budapest's Eotvos Lorand University, Dr Jozsef Fülöp, is a geologist with a special interest in prehistoric flint-mines.

In May, while still in his former post as president of the Central Geological Office, he arranged for the funding of a geophysical survey of the site, which traced the course of the gulley for future excavations. In 1986, moreover, Budapest will host an international archaeological conference on flint-mines, already arranged before the Farkasrét discoveries. It is now hoped that an on-site museum will be constructed next year and inaugurated during the 1986 conference.

Vera Rich 